\title{
Continuous biodiesel production under subcritical condition of methanol - Design of pilot plant and packed bed reactor with $\mathrm{MnCO}_{3} / \mathrm{Na}$-silicate catalyst
}

\author{
Hui Liu ${ }^{\mathrm{a}, *}$, Ivana Lukićb, Marija R. Miladinovićc, Vlada B. Veljkovićc, Miodrag Zdujićc,1, \\ Xiaosun Zhu ${ }^{\mathrm{a}}$, Yanan Zhang ${ }^{\mathrm{a}}$, Dejan U. Skala ${ }^{\mathrm{b}}$ \\ a State Key Laboratory of Biogeology and Environmental Geology and School of Environmental Studies, China University of Geosciences, Wuhan 430074, PR China \\ ${ }^{\mathrm{b}}$ University of Belgrade, Faculty of Technology and Metallurgy, Karnegijeva 4, 11000 Belgrade, Serbia \\ ${ }^{\mathrm{c}}$ University of Niš, Faculty of Technology, Bulevar oslobodjenja 124, 16000 Leskovac, Serbia \\ d Institute of Technical Sciences of the Serbian Academy of Sciences and Arts, Knez Mihailova 35, 11000 Belgrade, Serbia
}

\section{A R T I C L E I N F O}

\section{Keywords:}

Biodiesel

Subcritical methanolysis

Kinetic modeling

$\mathrm{MnCO}_{3} / \mathrm{Na}$-silicate catalyst

Pilot-plant design

\begin{abstract}
A B S T R A C T
The continuous biodiesel production from soybean oil was carried out under the subcritical condition of methanol with $\mathrm{MnCO}_{3} / \mathrm{Na}$-silicate as a heterogeneous catalyst. The transesterification rate was first investigated in a set of experiments performed in a batch autoclave at $448 \mathrm{~K}$ using methanol-to-oil molar ratio of 18:1 and various catalyst loadings (5, 10 and $20 \mathrm{wt} \%$ based on the oil mass). The results from these experiments, as well as the experimental data and the appropriate kinetic model recently reported in the literature were used for designing a packed bed tubular reactor (PBTR), a main unit of the pilot plant with the capacity of $100 \mathrm{~L}$ of biodiesel per day. The pilot plant was constructed and tested under various operating conditions. The first $11 \mathrm{~h}$ of the pilot-plant operation was realized in the tubular reactor packed with inert glass beads (i.e. without the catalyst) in order to analyze the effect of the non-catalyzed subcritical biodiesel (fatty acid methyl esters, FAME) production. Then, glass beads were replaced with a mix of $\mathrm{MnCO}_{3} / \mathrm{Na}$-silicate catalyst particles and glass beads, and the catalytic biodiesel production was continuously run under the subcritical methanol condition for $85 \mathrm{~h}$. Two mass balance tests during the continuous pilot plant operation were performed.
\end{abstract}

\section{Introduction}

In the past several years, many researchers have made efforts to synthesize efficient heterogeneous catalysts for biodiesel production in order to substitute the conventional technology based on homogeneous catalysis, which is currently applied in many industrial facilities. Numerous investigations have been undertaken in order to estimate the potential catalytic activity of both naturally originated and synthesized materials. Among the heterogeneous catalysts, the $\mathrm{CaO}$-based catalysts are frequently studied [1-5] due to their high activity and possibility to be obtained from inexpensive natural and waste materials [6]. The other low-cost materials, like $\mathrm{MnCO}_{3}$, Na-silicate and $\mathrm{MnCO}_{3} / \mathrm{Na}$-silicate, also show, after thermal activation, a high catalytic activity for biodiesel production [7-10]. Some of them, like Na-silicate, can be used even for transesterification of waste vegetable oils with a high amount of water owing to the hydolysisof the activated Na-silicate into $\mathrm{OH}^{-}$ and $\mathrm{Si}-\mathrm{O}-\mathrm{H}^{+}$, thus avoiding soap formation. Another advantage is the simple regeneration of the used Na-silicate catalyst with $\mathrm{NaOH}$ [7]. Other materials, like ion-exchange resins [11,12] and hydrotalcite [13], have also been tested in order to obtain long-lifetime catalysts that can be used for continuous processes.

Heterogeneously-catalyzed methanolysis reactions are slower than homogeneously-catalyzed ones due to the mass transfer limitations in the three-phase system mainly at the beginning of the transesterification process [14-16] The nature of heterogeneously catalyzed oil methanolysis reactions has been explained by different reaction mechanisms [17-22]. However, the resulting kinetic models based on these mechanisms are rather complex since a large number of parameters need to be determined. The recently reported studies described the suitable, relatively simple kinetic models of the vegetable oil methanolysis requiring no complicated computations [2,14]. The model proposed by Lukić et al. [14] is based on the pseudo-first order kinetics that involves the triacylglycerols (TAGs) mass transfer and chemical reaction controlled regimes. The model proposed by Miladinović et al.

\footnotetext{
* Corresponding author.

E-mail addresses: zliuhui@hotmail.com (H. Liu), miodrag.zdujic@itn.sanu.ac.rs (M. Zdujić).

${ }^{1}$ Co-corresponding author.
} 


\author{
Nomenclature \\ $c_{T A G} \quad$ concentration of TAG, mol/L \\ $c_{T A G, 0} \quad$ initial concentration of TAG, mol/L \\ $c_{w} \quad$ catalyst concentration, \% ( $w$, mass of catalyst per $100 \mathrm{~g}$ of \\ soybean oil) \\ $c_{p} \quad$ mass heat capacity of reaction mixture, $\mathrm{kJ} / \mathrm{kg} \cdot \mathrm{K}$ \\ $c_{\text {FAME }} \quad$ concentration of FAME, mol/L \\ d catalyst particle diameter, $\mathrm{mm}$ \\ $D A G \quad$ diacylglycerols \\ FAME fatty acid methyl esters \\ $F_{T A G, 0} \quad$ molar flow rate of TAGs, $\mathrm{mol} / \mathrm{min}$ \\ $\left(-\Delta H_{r}\right)$ heat effect of TAG transesterification reaction, $\mathrm{kJ} / \mathrm{mol}$ \\ $k_{\text {app }} \quad$ apparent reaction rate constant of transesterification pro- \\ cess, $\min ^{-1}$ \\ $k_{\mathrm{LT}} \quad$ reaction rate constant valid up to $423 \mathrm{~K}, \mathrm{~min}^{-1}$ \\ $k_{\mathrm{HT}} \quad$ reaction rate constant valid above $423 \mathrm{~K}, \mathrm{~min}^{-1}$ \\ $k_{a p p(w)} \quad$ apparent reaction rate constant as function of catalysts \\ concentration, $\min ^{-1}$ \\ $k_{m t}$ mass transfer coefficient during transesterification
}

$\begin{array}{ll} & \text { process, } \min ^{-1} \\ k_{m t 0} & \begin{array}{l}\text { mass transfer coefficient at the beginning of transester- } \\ \text { ification process, } \text { min }^{-1}\end{array} \\ m_{0} & \text { mass flow rate of reaction mixture, } \mathrm{kg} / \mathrm{h} \\ m_{T A G, 0} & \text { mass flow rate of TAGs into PBTR, } \mathrm{kg} / \mathrm{h} \\ M_{0} & \text { molar flow rate of reaction mixture, mol/h } \\ M A G & \text { monoacylglycerols } \\ \left(-r_{\mathrm{TAG}}\right) & \text { rate of triacylglycerols transesterification, } \mathrm{mol} /(\mathrm{min} \cdot \mathrm{L}) \\ t & \text { time, min } \\ T & \text { temperature, } \mathrm{K} \\ T A G & \text { triacylglycerols } \\ V & \text { volume of reaction mixture, } \mathrm{L} \\ x_{T A G} & \text { degree of TAG conversion }\end{array}$

Greek symbols

$\alpha \quad$ parameter of kinetic model, Eq. (3b)

$\beta \quad$ parameter of kinetic model, Eq. (3b)

$\tau \quad$ residence time, $\min$
[2] includes a changing reaction mechanism with respect to TAGs and the first order reaction with respect to fatty acid methyl esters (FAMEs). The applicability of both models was confirmed for the sunflower oil methanolysis catalyzed by the CaO-based catalysts ( $\mathrm{CaO} \cdot \mathrm{ZnO}$, pure $\mathrm{CaO}$ and quicklime) under various reaction conditions [23,24]. They were applied and verified under continuous conditions at small scale, too $[13,23]$.

The continuous methanolysis has been investigated at both atmospheric pressure and moderate temperature [11,21,25-28] and high pressure and temperature [29-33]. However, the most of the reported studies were conducted in laboratory scale devices for a short period of time [34]. Kouzu et al. reported the pilot scale transesterification of the waste cooking oil in the higher volume reactor $(150 \mathrm{~L})$, but it was performed in a stirred tank reactor with powdery $\mathrm{CaO}$ catalyst since it was concluded that the CaO-catalyzed transesterification is difficult to perform with the fixed bed reactor, due to the mass transfer limitations as well as plausible crushing of catalysts particles [35]. Catalysts used in powder form in the packed bed reactors caused blocking of the flow of the reactants throughout the catalyst bed by particle agglomeration [28] and high pressure drop inside small column at the end of the experiment due to the very dense packed bed formed [8]. Also, separation of the solid catalyst in powder form from the products of transesterification is difficult, thus, important issue for packed bed reactors, which are commonly used for continuous heterogeneously catalyzed processes at the industrial scale, is the use of coarse catalyst particles, with good mechanical strength that would not collapse during the process.

The recent investigations of the heterogeneously catalyzed oil transesterification with subcritical methanol have been aimed at improving the process efficiency, i.e. at reducing the temperature, pressure and methanol-to-oil molar ratio applied under supercritical noncatalyzed vegetable oil methanolysis. Furthermore, the problem of a huge amount of waste water generated during the homogeneous transesterification and biodiesel purification, could be easily avoided by conducting the transesterification with subcritical methanol and an appropriate solid catalyst [36].

Common reaction conditions for various heterogeneous catalysts at higher temperature and pressure are $>150{ }^{\circ} \mathrm{C}$ and $>30$ bar [37-40] and the methanol-to-oil molar ratio higher than 15:1 (methanol is in subcritical or supercritical condition) [41,42]. High temperature synthesis have recently been applied with $\mathrm{MnCO}_{3}, \mathrm{MnCO}_{3} / \mathrm{Na}$-silicate $[8,9]$ and $\mathrm{MnCO}_{3} / \mathrm{ZnO}$ [43] catalysts in the form of powder or granules (coarse particles). Furthermore, it is worth mentioning that methanol- to-oil molar ratio and reaction temperature applied in the biodiesel production with $\mathrm{MnCO}_{3}$ or $\mathrm{MnCO}_{3} / \mathrm{Na}$-silicate catalyst were lower than those suggested by Yin et al. [44] for the subcritical sodium silicatecatalyzed soybean oil methanolysis. The $\mathrm{MnCO}_{3} / \mathrm{Na}$-silicate catalyst prepared in the form of granulated particles have an acceptable activity, excellent selectivity towards FAME formation from TAGs, and acceptable lifetime at high temperature [9].

This article reports designing and testing of a pilot plant applied for the biodiesel production by the soybean oil transesterification catalyzed by $\mathrm{MnCO}_{3} / \mathrm{Na}$-silicate with the capacity of $100 \mathrm{~L}$ of biodiesel per day. Results of the recently reported study [9] supplemented with information from several additional experiments realized in batch autoclave with different amount of $\mathrm{MnCO}_{3} / \mathrm{Na}$-silicate $(5-20 \mathrm{wt} \%$ based on oil) at $448 \mathrm{~K}$ and 18:1 methanol to oil molar ratio, were the basis for design of packed bed tubular reactor (PBTR) as main equipment of corresponding pilot plant. PBTR was filled with $\mathrm{MnCO}_{3} / \mathrm{Na}$-silicate as catalyst mixed with inert glass beads and such reactor was applied for continuous transesterification at subcritical condition of methanol. Test of continuous operation was used to prove designed capacity and operational characteristics of pilot plant unit during $100 \mathrm{~h}$ of operation. Investigation was started using PBTR filled only with glass beads for $11 \mathrm{~h}$, and then, the catalyzed transesterification of soybean oil with $\mathrm{MnCO}_{3} / \mathrm{Na}$-silicate as catalyst was realized during $85 \mathrm{~h}$ of continuous operation. Two complete mass balances were determined for detailed examination of the content of produced biodiesel while sample of used catalyst after $85 \mathrm{~h}$ of continuous process was withdrawn from reactor and its characteristics were analyzed using XRD, TG/DSC and FTIR.

\section{Materials and methods}

\subsection{Catalyst preparation}

The preparation and characterization of the $\mathrm{MnCO}_{3} / \mathrm{Na}$-silicate catalyst have recently been reported [9]. The catalyst was activated by drying at $473 \mathrm{~K}$ for $2 \mathrm{~h}$, followed by the calcination in an oven at $773 \mathrm{~K}$ for $3 \mathrm{~h}$.

\subsection{Experimental procedure}

\subsubsection{Batch reactor}

The soybean oil transesterification was conducted in $300 \mathrm{~mL}$ batch autoclave (AE - Autoclave Engineers, USA), with an electrical heater and a Rushton-type mixer $(560 \mathrm{rpm})$ at the methanol to soybean oil 
ratio of $18: 1,448 \mathrm{~K}$ [45] and different $\mathrm{MnCO}_{3} / \mathrm{Na}$-silicate catalyst amounts (5, 10 and $20 \mathrm{wt} \%$ of the mass of oil). The reaction mixture samples withdrawn from the batch autoclave was analyzed as recently described $[9,45]$. The standard deviation for all experiments was determined to be $\pm 2.86 \%$.

\subsubsection{Pilot plant}

A pilot plant with a PBTR, designed on the basis of the kinetic data obtained in the laboratory batch reactors, was constructed and used for biodiesel production from soybean oil. During the test of the pilot-plant capacity and the catalyst activity, the following parameters were monitored: pressure, temperature and the mass flow rates of the reactants (methanol and soybean oil) while the masses of the produced biodiesel and glycerol were measured. Two tests during the continuous soybean oil transesterification were conducted:

(1) the non-catalyzed reaction in the PBTR only filled with $2 \mathrm{~mm}$ glass beads for $11 \mathrm{~h}$ (so called ZERO test) and

(2) the catalyzed reaction in the PBTR filled with a mix of $2 \mathrm{~mm}$ glass beads and catalyst particles $(0.99<d<1.99 \mathrm{~mm})$ in the proportion $60: 40$ by weight for $85 \mathrm{~h}$ (so called LONG TERM test, $L T-t$ ).

\subsubsection{Catalyst characterization}

The properties of the used catalyst (withdrawn from the PBTR after $85 \mathrm{~h}$ of continuous operation) were characterized by X-ray diffraction (XRD) on a Philips PW 1050 X-ray powder diffractometer using Ni-filtered $\mathrm{Cu} \mathrm{K \alpha _{1,2 }}(\lambda=1.54178 \AA)$ radiation with a scanning step width of $0.05^{\circ}$ and a counting time of $3 \mathrm{~s}$ per step, thermal analysis (TG/DTA) on a Setaram Instrument between $293 \mathrm{~K}$ and $1273 \mathrm{~K}$ in air flow $\left(20 \mathrm{~K} \mathrm{~min}^{-1}\right)$ and Furrier transformed infrared spectroscopy (FTIR) using a BOMEM spectrometer (Hartmann \& Braun) in the wave number range of $4000-400 \mathrm{~cm}^{-1}$ with $4 \mathrm{~cm}^{-1}$ resolution.

\section{Results and discussion}

\subsection{Analysis of soybean oil transesterification in a batch reactor}

The soybean oil transesterification in the presence of the $\mathrm{MnCO}_{3} /$ Na-silicate catalyst occurs via two simultaneous catalytic processes [9]: one is catalyzed heterogeneously by both active species ( $\mathrm{Mn}$ and $\mathrm{Na}$ ) fixed on the surface of solid catalyst particles and homogeneously by $\mathrm{Na}$ dissolved in the esters and methanol/glycerol phases. It is important to point out that the batch transesterification reaction takes place during the heating of the reaction mixture from the room temperature to the specified reaction temperature (non-isothermal regime), and while keeping the reaction temperature constant (isothermal regime). The apparent reaction rates are simply defined by the reaction rate constants, $k_{\mathrm{LT}}$ and $k_{\mathrm{HT}}$, depending on the reaction temperature and determined for the process performed with $5 \mathrm{wt} \%$ of the catalyst (based on the oil) [9]:

$k=k_{\mathrm{LT}}=7.918 \exp (-2465 / T), \min ^{-1}$ for $T<423 \mathrm{~K}$

$k=k_{\mathrm{HT}}=6.355 \times 10^{5} \exp (-7272 / T), \min ^{-1}$ for $T>423 \mathrm{~K}$

The rate of TAG conversion was defined by the following kinetic Eq. [9]:

$\frac{d x_{T G}}{d t}=k_{a p p}\left(1-x_{T G}\right)$

where $k_{\text {app }}$, according to the IL kinetic model, is defined as follows:

$k_{\text {app }}=\frac{k \cdot k_{m t}}{k+k_{m t}}=\frac{k_{a p p} \cdot k_{m t 0} \cdot\left[1+\alpha\left(x_{T A G}\right)^{\beta}\right]}{k_{a p p}+k_{m t 0} \cdot\left[1+\alpha\left(x_{T A G}\right)^{\beta}\right]}$

The best agreement between the calculated and experimentally determined TAG conversion degrees was obtained using the values of the reaction rate constant $k$ (i.e. $k_{\mathrm{LT}}$ or $k_{\mathrm{HT}}$ ), the initial value of the mass transfer coefficient $k_{\mathrm{mt} 0}=0.085 \mathrm{~min}^{-1}$, and the values of the parameters $\alpha=55$ and $\beta=3.5$ [9].

\subsection{Analysis of the transesterification in the batch reactor performed with different amounts of catalyst}

In the present study, several experiments were conducted in the $\mathrm{AE}$ batch reactor using $5 \%, 10 \%$ and $20 \%$ of $\mathrm{MnCO}_{3} / \mathrm{Na}$-silicate catalyst based on mass of oil (particle size $0.99-1.99 \mathrm{~mm}$ ) at $448 \mathrm{~K}$ to verify the proposed IL kinetic model at higher catalyst amounts [9]. Besides, unlike previously reported results [9] the isothermal temperature of $448 \mathrm{~K}$ in this study was reached in the batch autoclave for $113 \mathrm{~min}$. The difference in the heating time needed to reach the isothermal transesterification temperature in the batch autoclave could give additional information about the flexibility of the proposed IL kinetic model used to predict TAG conversion at $448 \mathrm{~K}$.

The experiments with $5 \%$ of catalyst (based on oil) showed that the TAG conversion of $62.6 \%$ was obtained during heating period of $113 \mathrm{~min}$ ( $54.6 \%$ for $54 \mathrm{~min}$ [9]), while TAG conversion of $81.3 \%$ and $98.2 \%$ were obtained with $10 \%$ and $20 \%$ of catalyst, respectively for the same time of non-isothermal heating. Further $1 \mathrm{~h}$ of isothermal transesterification at $448 \mathrm{~K}$ with $5 \%$ and $10 \%$ of catalyst gave almost the complete TAG conversion ( $>99 \%$ ). According to these data the following recalculations of the reaction apparent rate constant $k$ (i.e. $k_{\mathrm{LT}}$ and $k_{\mathrm{HT}}$ ) and mass transfer coefficient $k_{\mathrm{mt} 0}$, which depended on the total catalytic surface area [8], were used to determine the reaction rate constant $k_{\text {app }}$ applicable for both non-isothermal (heating to $448 \mathrm{~K}$ ) and isothermal regime:

$k_{(w)}=k_{(5)} \frac{c_{c a t}(w)}{c_{\text {cat }(5)}}$

and

$k_{m t 0(w)}=k_{m t 0(5)} \frac{c_{c a t}(w)}{c_{c a t}(5)}$

thus leading to:

$k_{\text {app }(w)}=k_{\text {app }(5)} \frac{c_{\text {cat }(w)}}{c_{\text {cat }(5)}}$

where $c_{c a t(w)}$ is the catalyst amount used for the transesterification of soybean oil (valid for $2<w<8 \mathrm{wt} \%$ based on the mass of oil).

Furthermore, recently reported results showed only a slight increase of TAG conversion (to $95 \%$ ) during heating to $428 \mathrm{~K}$ and $1 \mathrm{~h}$ of isothermal transesterification at $428 \mathrm{~K}$ with increasing the catalyst amount from 8 to $13 \%$ [9], which implied that the apparent reaction rate constant $\left(k_{a p p(w)}\right)$ depended almost linearly on the catalyst concentration only in the range of catalyst amount between $2 \%$ and $8 \%$, as shown by Eq. (4).

The relation between $k_{\mathrm{app}(\mathrm{w})}$ and catalyst concentration might deviate from the linear dependence (valid for $5<w<8$, Table 1), when larger catalyst concentrations are used. Namely, the apparent reaction rate constant $k_{a p p(w)}$, as a "lumped parameter", includes the resistance of TAG mass transfer to the surface of catalyst particles and the resistance of chemical reaction between TAGs and methoxide ions at the catalyst surface. These resistances have different and specific relation to temperature and catalyst concentration. The mass transfer coefficient is related to square root of temperature $\left(T^{0.5}\right)$ while the chemical reaction rate constant is an exponential function of temperature according to the Arrhenius equation. Also, the resistance of chemical reaction can be correlated directly to the catalyst concentration (i.e. to the available catalyst surface area) while the resistance of mass transfer depends on the hydrodynamic conditions in the reactor (mixing, viscosity). Therefore, the relation between $k_{a p p(w)}$ and catalyst concentration may be non-linear, as shown in some recently reported investigations [8].

While the linear correlation between $k_{a p p(w)}$ and catalyst concentration was assumed for the catalyst concentration between 2 and 
Table 1

Experimental results of the soybean oil transesterification during non-isothermal heating from $288 \mathrm{~K}$ to $448 \mathrm{~K}$ and subsequent isothermal heating at $448 \mathrm{~K}$ for $1 \mathrm{~h}$.

\begin{tabular}{|c|c|c|c|c|c|c|}
\hline \multirow{2}{*}{$\begin{array}{l}M_{\text {cat }} \\
\text { based } \\
\text { on the } \\
\text { mass } \\
\text { of oil } \\
\text { (wt } \% \text { ) }\end{array}$} & \multirow{2}{*}{$\begin{array}{l}\text { Operation } \\
\text { regime }\end{array}$} & \multirow{2}{*}{$\begin{array}{l}\text { Time } \\
\text { (min) }\end{array}$} & \multirow[t]{2}{*}{ Temperature (K) } & \multirow{2}{*}{$\begin{array}{l}x_{\mathrm{TAG}}, \\
\exp \\
(\%)\end{array}$} & \multicolumn{2}{|c|}{$x_{\mathrm{TAG}, \text { calculated }}(\%)$} \\
\hline & & & & & $\begin{array}{l}\text { After } \\
113 \mathrm{~min}\end{array}$ & $\begin{array}{l}\text { At the end } \\
\text { of } \\
\text { isothermal } \\
\text { operation }\end{array}$ \\
\hline \multirow[t]{2}{*}{5} & Heating & 113 & $288 \rightarrow 448$ & 62.6 & 66.9 & - \\
\hline & $\begin{array}{l}\text { Isothermal } \\
\text { operation }\end{array}$ & 60 & 448 & 98.3 & - & 98.8 \\
\hline \multirow[t]{2}{*}{10} & Heating & 113 & $288 \rightarrow 448$ & 81.3 & 88.7 & - \\
\hline & $\begin{array}{l}\text { Isothermal } \\
\text { operation }\end{array}$ & 60 & 448 & 97.2 & - & 99.9 \\
\hline \multirow[t]{2}{*}{20} & Heating & 113 & $288 \rightarrow 448$ & 98.2 & 95.9 & - \\
\hline & $\begin{array}{l}\text { Isothermal } \\
\text { operation }\end{array}$ & 60 & 448 & 99.9 & - & 100 \\
\hline
\end{tabular}

$8 \%$, a different correlation was proposed for the catalyst concentration higher than $8 \%$ (i.e. $10 \%$ and $20 \%$ in this study) according to relation:

$k_{\text {app }(w)}=\varphi k_{\text {app }(5)}$

$\varphi=1.6\left[2-\exp \left(\frac{8-w}{8}\right)\right]$

which means that the maximal increase of the apparent reaction rate constant might be 2 times related to the value determined or 3.2 times higher than the value valid when $8 \%$ or $5 \%$ of catalyst is used, respectively. Thus, for the experiments conducted in the batch autoclave (300 mL, $560 \mathrm{rpm}$ ), the corresponding values of $k_{\text {app }}$ and two other kinetic model parameters $(\alpha=55$ and $\beta=3.5$, accepted from the previous work [9]) were used for calculation and comparison with the experimentally determined TAG conversions (Table 1).

An excellent agreement between the calculated and experimentally determined TAG conversions at the end of non-isothermal heating (113 $\mathrm{min}$ ) and the end of the overall process was observed as confirmed by small mean relative percentage deviations $(4.4 \%$ and $1.6 \%$, respectively). These results proved the proposed and used correlation between the apparent reaction rate constant and the applied catalyst amount and validated the kinetic parameters involved in the IL kinetic model.

\subsection{Design of packed bed tubular reactor}

Since the methanolysis reaction was performed in the batch stirred reactor with perfect mixing, the design equation coming out from the mole balance of TAG is the same for the PBTR with ideal plug flow. In order to calculate the residence time of the reaction mixture in the pilot PBTR operating under adiabatic condition, the following differential equations of mole and energy balances were applied:

$\begin{aligned} \frac{d x_{T A G}}{d \tau} & =k_{a p p}\left(1-x_{T A G}\right) \\ \frac{d T}{d x_{T A G}} & =-\frac{F_{T A G, 0} \Delta H_{r}}{m_{0} c_{p}}\end{aligned}$

Using Eqs. (5a) and (5b) and assuming that the catalyst-to-oil mass ratio in the reactor would be much higher than $20 \%$, the following equation, that connects reaction rate constant with temperature, was used to calculate the $k_{\text {app }}$ values:

$k=3.2 \cdot k_{H T(w=5 \%)}=2.034 \times 10^{6} \exp \left(-\frac{7272}{T}\right), \mathrm{min}^{-1}$

Simultaneous solution of Eqs. (6) and (7) for the initial condition:

$X_{T A G}=0$ for $\tau=0$ and $T(0)=T_{\text {in }}=443 \mathrm{~K}$

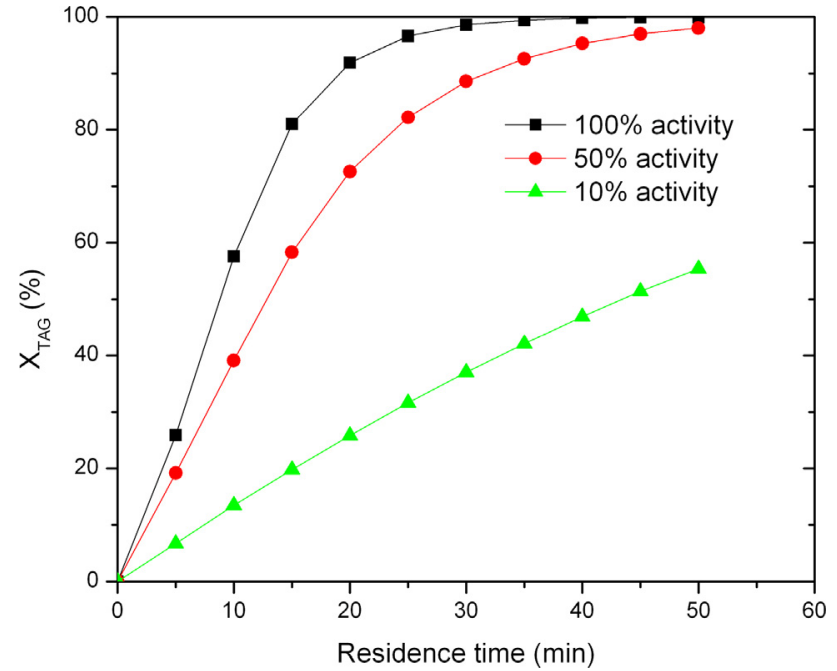

Fig. 1. Conversion degree versus residence time of the reaction mixture for different average catalyst activities in the PBTR.

gave the TAG conversion degree, $x_{T A G}$, and the temperature at the outlet of the reactor, $T_{e x}$, for the residence time of $\tau=50 \mathrm{~min}$. The values of the specific heat, $c_{p}$, and the heat of reaction, $\left(-\Delta H_{\mathrm{r}}\right)$, were taken from the literature [46].

For the initial activity of catalyst (100\%), almost complete TAG conversion $\left(x_{\mathrm{TAG}}=1\right.$ or $100 \%$ ) could be obtained at the outlet of the reactor after $50 \mathrm{~min}$ of residence time. If the catalyst activity in the PBTR dropped to $50 \%$ of its initial value, then the TAG conversion degree at the reactor outlet would be $98 \%$. Further decrease of the average catalyst activity in the PBTR, e.g. to $10 \%$ of its initial activity would result in 55\% TAG conversion degree, as shown in Fig. 1.

The design of the PBTR having capacity of $100 \mathrm{~L} /$ day was based on the following assumptions:

- The process efficiency of $90 \%$ was adopted, resulting the biodiesel production capacity of $4.17 \mathrm{~kg} / \mathrm{h}(0.07 \mathrm{~kg} / \mathrm{min})$.

- For the complete conversion of soybean oil (>99\%), the inlet soybean oil (TAG) mass flow rate $\left(m_{\mathrm{o}, \mathrm{TAG}}\right)$ should be $4.17 \mathrm{~kg} / \mathrm{h}$.

- Taking into account the molar masses of soybean oil $(890 \mathrm{~g} / \mathrm{mol})$ and methanol $(32 \mathrm{~g} / \mathrm{mol})$ and their molar ratio of $1: 18$, the inlet concentration of TAGs, represented by triolein as a key compound $\left(c_{T A G o}\right.$ ) would be $0.60 \mathrm{~mol} / \mathrm{L}$, while the molar and mass flow rates of the reaction mixture $\left(M_{\mathrm{o}}\right.$ and $\left.m_{\mathrm{o}}\right)$ into the PBTR would be $89 \mathrm{~mol} / \mathrm{h}$ and $6870 \mathrm{~g} / \mathrm{h}$, respectively; the inlet TAG molar flow rate of $\left(F_{T A G o}\right)$ was $4.68 \mathrm{~mol} / \mathrm{h}$.

- The catalyst bed would be prepared by mixing $\mathrm{MnCO}_{3} / \mathrm{Na}$-silicate catalyst particles (bulk density of $1.2 \mathrm{~g} / \mathrm{mL}$ ) and inert glass beads (2 $\mathrm{mm} ; 2.5 \mathrm{~g} / \mathrm{mL}$ ) with the mass ratio of $40: 60$.

- The porosity of the catalyst bed was assumed to be $50 \%$.

- The proposed residence time of the reaction mixture in the PBTR would be 50 min.

- The reaction mixture would be heated in a preheater to $448 \mathrm{~K}$ to the reaction temperature in the PBTR.

- The inlet mass flow rates of the soybean oil and methanol would be $6870 \mathrm{~g} / \mathrm{h}$ or $8.6 \mathrm{~L} / \mathrm{h}$, corresponding to the methanol-to-oil molar ratio of 18: 1 .

- The density of the reaction mixture at $448 \mathrm{~K}$ and 25 bar was assumed to be about $800 \mathrm{~kg} / \mathrm{L}$.

- A simple calculation gave the volume of the reaction mixture which occupied the void space of the bed of $7.16 \mathrm{~L}$ and the volume of the empty reactor of $14.33 \mathrm{~L}$. Thus, the reactor could be packed with $8.33 \mathrm{~L}$ of $\mathrm{MnCO}_{3} / \mathrm{Na}$-silicate catalyst (or $10 \mathrm{~kg}$; density $1.2 \mathrm{~kg} / \mathrm{L}$ ) and $6 \mathrm{~L}$ of inert glass beads (spheres) $(15 \mathrm{~kg}$; density of $2.5 \mathrm{~kg} / \mathrm{L})$.

- The amount of oil in the reactor would be $3.90 \mathrm{~kg}$, so the catalyst 
concentration (based on the mass of oil) in the reactor would be 10/ $3.90=2.56 \mathrm{~kg} / \mathrm{kg}$ or $256 \%$.

The final design of the PBTR was based on the following:

(a) Volume of the tubular reactor would be $14 \mathrm{~L}$.

(b) Mass of $10.2 \mathrm{~kg}$ of catalyst particles (cylindrical granules with the average diameter between 0.9 and $1.99 \mathrm{~mm}$ ) and mass of $15.3 \mathrm{~kg}$ of glass beads $(2 \mathrm{~mm})$, respectively should be used for preparing the packed bed.

(c) The biodiesel production capacity would be $4.05 \mathrm{~kg} / \mathrm{h}$ or $97 \mathrm{~kg}$ / day, i.e. slightly above $100 \mathrm{~L} /$ day (density of biodiesel: $0.9 \mathrm{~kg} / \mathrm{L}$ ).

3.4. Assessment of catalyst deactivation during long-term continuous operation

The catalyst activity in the successive batches was evaluated in the batch autoclave with the same amount of catalyst (10 $\mathrm{wt} \%$ based on the
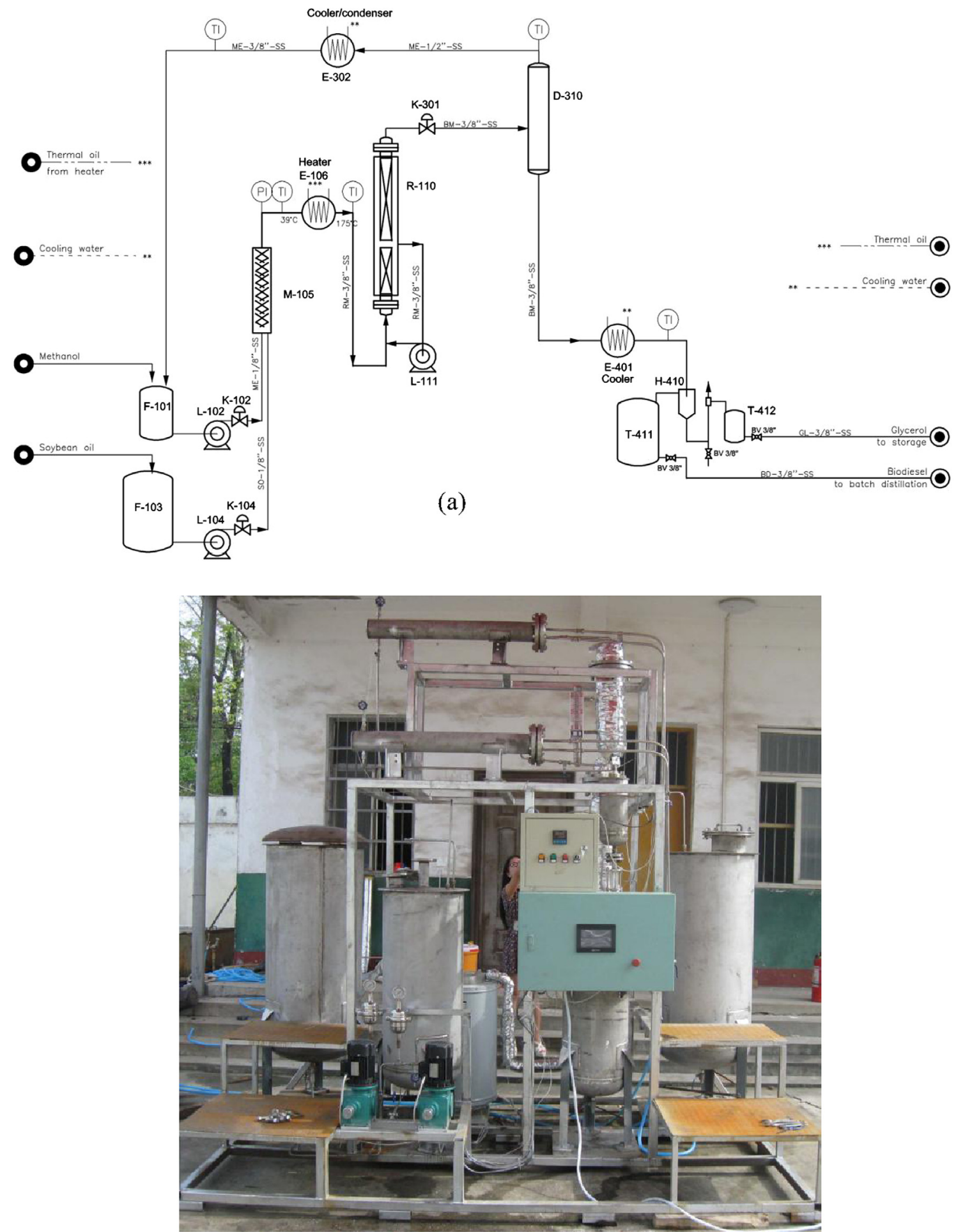

(b)

Fig. 2. The pilot plant for FAME synthesis: (a) layout and (b) photo. 
oil weight) at $458 \mathrm{~K}$ and with the $30: 1$ methanol-to-oil molar ratio [9]. It was found that the catalyst might be reused 8-9 times without substantial decrease of the TAG conversion degree (from $100 \%$ to $97.4 \%$ ) but with the change of FAME yield from $99 \%$, to $92.6 \%$ and $88.3 \%$ after 8 th and 9th catalyst reuse, respectively [9]. Therefore, $10 \mathrm{~kg}$ of the catalyst placed in the PBTR could be used for processing $800 \mathrm{~kg}$ of soybean oil. In other words, the catalyst might be used for 8-day continuous operation of the PBTR when TAG conversion degree would be slightly decreased to $97.4 \%$. However, the catalyst activity after 8 days of continuous operation would be only $35 \%$ of the initial activity.

\section{Pilot plant design}

The main steps of the proposed continuous biodiesel production are the mixing of oil and methanol and preheating their mixture to the reaction temperature, the transesterification of soybean oil in the PBTR, the separation of the excess of methanol, the separation of biodiesel and glycerol and the purification of biodiesel and glycerol. In order to reduce the overall investment and operational costs of the pilot plant operation, only the capacity of the pilot plant was tested while the downstream glycerol and biodiesel purification was not considered at the present stage of the pilot plant construction. Hence, the main process scheme included:

- pumping, mixing and preheating of methanol and oil;

- flowing of the soybean oil/methanol mixture into the PBTR;

- flash separation of the excess of methanol from the reaction mixture; and

- separation of biodiesel (upper) and glycerol (lower) layer.

The process flow sheet with the main streams and units is shown in Fig. 2a while the photo of the pilot plant is presented in Fig. 2b. The main equipment units of the pilot plant are specified in Table 2.

The proposed operation conditions for the biodiesel production in the pilot plant facility were the methanol to soybean oil molar ratio of $18: 1$, the reaction temperature of $448 \mathrm{~K}$ and the maximal working pressure of 30 bar. The minimal TAG conversion degree achieved in the PBTR after 8th day of the use the $\mathrm{MnCO}_{3} / \mathrm{Na}$-silicate catalyst was assumed to be $97.4 \%$. After 8 days of continuous operation, the catalyst must be replaced by a packed-bed of fresh catalyst.

\subsection{Analysis of operating parameters}

The main objectives of testing the pilot plant were to investigate the soybean oil methanolysis catalyzed by $\mathrm{MnCO}_{3} / \mathrm{Na}$-silicate for the biodiesel production under the conditions established in the laboratory batch reactor and to prove the designed capacity of the pilot plant.

\subsubsection{Pilot plant testing}

First, the pilot plant was tested on the leakage and the pressure by flowing the tap room temperature water (so-called cold test) and then soybean oil preheated in the preheater to $175^{\circ} \mathrm{C}(448 \mathrm{~K})$ at the flow rate of $6.3 \mathrm{~L} / \mathrm{h}$ (maximum capacity of the pump). The pilot plant comprised the system for monitoring (measuring and manual control) temperature of the heater, the reactor (inside the packed bed, in the jacket and the reactor outlet), the flash evaporator, the condenser and the cooler as well as the system for measuring the pressure at the inlet and outlet of the reactor.

\subsubsection{Non-catalyzed FAME synthesis in pilot plant (ZERO test)}

After passing through the static mixer (M-105) and the preheater (E106), methanol and soybean oil were pumped into the PBTR (R-110). The residence time of the reaction mixture in the preheater and the connecting pipeline between the preheater and the PBTR enabled only a minimal effect of the non-catalyzed transesterification [36]. The variation of temperature, which was controlled at several points of the pilot plant, during $11 \mathrm{~h}$ of the non-catalyzed FAME synthesis is shown in Fig. 3.

The temperature of the reactants leaving the preheater was slightly higher than the desired reaction temperature of $175^{\circ} \mathrm{C}$ as well as the temperature inside the reactor. However, the measured temperature of the reaction mixture at the reactor outlet was about $155^{\circ} \mathrm{C}$ at the beginning of the non-catalyzed (so-called ZERO test). This was attributed to the temperature sensor position which was mounted on the outside surface of the reactor wall. The detected temperature at the top of the flash evaporator was lower than the desired one $\left(>80^{\circ} \mathrm{C}\right)$, which was explained also by the position of the temperature sensor which was placed on the outside surface of the evaporator. The temperatures in the condenser and the cooler were relatively stable.

The contents of FAMEs, TAGs, DAGs and MAGs in the samples of the reaction mixture taken at the outlet of the heater (inlet into the reactor) and the outlet of the reactor during the ZERO test $(t=0,3,7,9$ and $11 \mathrm{~h}$ ) were determined. Only the presence of about $6 \%$ of DAGs and a negligible concentration of MAGs $(0.7 \%)$ were detected in the samples at the inlet of the reactor. These data indicate that the reaction started even in a relatively short residence time of the reactants in the heater and the connecting pipeline. The HPLC analysis of the esters phase separated from the samples taken at the outlet of the reactor showed the following average contents: $60 \%$ of TAGs, $22.5 \%$ of FAME or biodiesel, $11.5 \%$ of DAGs and $6 \%$ of MAGs during $11 \mathrm{~h}$ of non-catalyzed transesterification. Thus, for the applied residence time of oil in the empty tubular reactor, the non-catalyzed conversion of TAGs of about $40 \%$ was achieved and that about $50 \%$ of TAGs were converted into FAMEs.

\subsubsection{Catalyzed synthesis of FAMEs in the PBTR (Long TERM test, LT-t)}

After the non-catalyzed reaction was completed, the reactor was discharged, and filled with catalyst particles and glass beads (mass ratio of $2: 3 ; 10 \mathrm{~kg}$ of $\mathrm{MnCO}_{3} / \mathrm{Na}$-silicate catalyst and $15 \mathrm{~kg}$ of glass beads; 0.51 was experimentally determined porosity of catalyst bed). Methanol and soybean oil were heated to $175^{\circ} \mathrm{C}$ and kept at this temperature for $30 \mathrm{~min}$. After that, the mixture of the preheated reactants was fed to the reactor bottom. The temperature of the reaction mixture (mainly soybean oil and methanol) at the outlet of the preheater was close to the temperature inside the reactor and did not exceed $190^{\circ} \mathrm{C}$, thus preventing the overheating of soybean oil and the unwanted side reactions (e.g. polymerization). This temperature was achieved with the temperature of heating oil in the heater in the range from $180^{\circ} \mathrm{C}$ to $210^{\circ} \mathrm{C}$ (Fig. 4b). The average pressure in the reactor was $2.5 \mathrm{MPa}$ during the $L T-t$ and slightly lower during the FIRST mass balance of the $L T-t$, compared to the average pressure during the SECOND mass balance of the $L T$ - $t$ (Fig. 4a). The temperature inside the PBTR varied in the range from $175^{\circ} \mathrm{C}$ to $195{ }^{\circ} \mathrm{C}$ (Fig. $4 \mathrm{~b}$ ).

Considering the methanol-to-oil molar ratio (18:1 and 25:1)

Table 2

The main units of pilot plant.

\begin{tabular}{llll}
\hline Unit & Used as & Dimensions & Volume \\
\hline F-101 & Storage tank for oil & $\varnothing 600 \times 1200 \mathrm{~mm}$ & $0.4 \mathrm{~m}^{3}$ \\
F-103 & Storage tank for methanol & $\varnothing 450 \times 1000 \mathrm{~mm}$ & $0.176 \mathrm{~m}^{3}$ \\
M-105 & Static mixer & DN15 & - \\
E-106 & Preheater & $380 \mathrm{~V}, 10 \mathrm{~kW}$ & - \\
R-110 & Reactor & $\varnothing 133 \times 5 \mathrm{~mm}$ & $0.019 \mathrm{~m}^{3}$ \\
& & $\mathrm{H}=1400 \mathrm{~mm}$ & \\
D-310 & Flash evaporator & $\varnothing 159 \times 4 \mathrm{~mm}$ & $0.01 \mathrm{~m}^{3}$ \\
& & $\mathrm{H}=500 \mathrm{~mm}$ & \\
E-302 & Condenser for methanol & $\mathrm{A}=0.004 \mathrm{~m}^{2}$ & - \\
E-401 & Cooler of FAME-glycerol mixture & $\mathrm{A}=0.008 \mathrm{~m}$ & - \\
T-411 & Separator & $\varnothing 159 \times 4 \mathrm{~mm}$ & $0.006 \mathrm{~m}^{3}$ \\
& & $\mathrm{H}=300 \mathrm{~mm}$ & \\
F-104 & Storage tank for FAME & $\varnothing 600 \times 1200 \mathrm{~mm}$ & $0.33 \mathrm{~m}^{3}$ \\
F-105 & Storage tank for glycerol & $\varnothing 377 \times 500 \mathrm{~mm}$ & $0.06 \mathrm{~m}^{3}$ \\
\hline
\end{tabular}




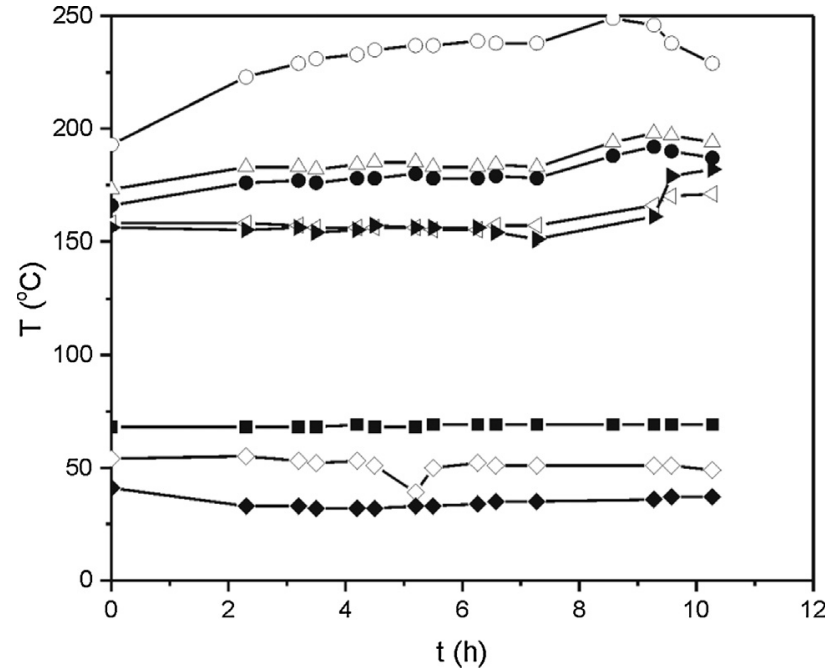

Fig. 3. Variations of temperature at the measuring points during the non-catalyzed synthesis of FAMEs (thermal oil at the heater inlet - $\bigcirc$; the reactants' mixture at the heater outlet - - ; the reactor $-\triangle$; the reactor jacket $-\triangleleft$; the reactor outlet $-\square$; the evaporator $-\square$; the condenser $-\diamond$; and, the cooler $-\diamond$ ). employed in this process during the FIRST and SECOND mass balances, certain difficulties in the separation of the final products could be expected. Therefore, the flash evaporator (D-310, Fig. 2a) was included in the pilot plant facility, where the excess methanol from the outlet reaction mixture was removed by partial vaporization, enhancing the separation between esters and glycerol phases due to their poor mutual solubility. The temperature of $69^{\circ} \mathrm{C}$ in the flash evaporator used for removing the excess of methanol from the ester and glycerol mixture was constant (Fig. 4c). After the flash evaporation step, the outlet stream of the main transesterification products, consisting of esters and glycerol phases, pass through the cooler to a gravitational separator.

Generally, the measured temperatures at the outlet of the preheater, the inlet and outlet of the reactor, as well as at the surface of the flash evaporator, were stable, without extreme fluctuation. However, the pilot plant did not have the system for automatic control of temperature in the reactor, so it was regulated manually, thus making difficult to maintain stable both the pressure and the temperature in the reactor at the desired levels, as can be seen in Fig. 4.

Two complete mass balances were realized (highlighted area in Fig. 4) aimed at determining the actual mass flow rates of the reactants and the products and the composition of biodiesel after its separation from glycerol. The masses of different fractions were collected at inlet and outlet of the reactor during the FIRST (between 11th and 21th $\mathrm{h}$ of operation) and SECOND (between 81th and 86th h of operation) mass balance and measured on scale; the obtained masses are presented in

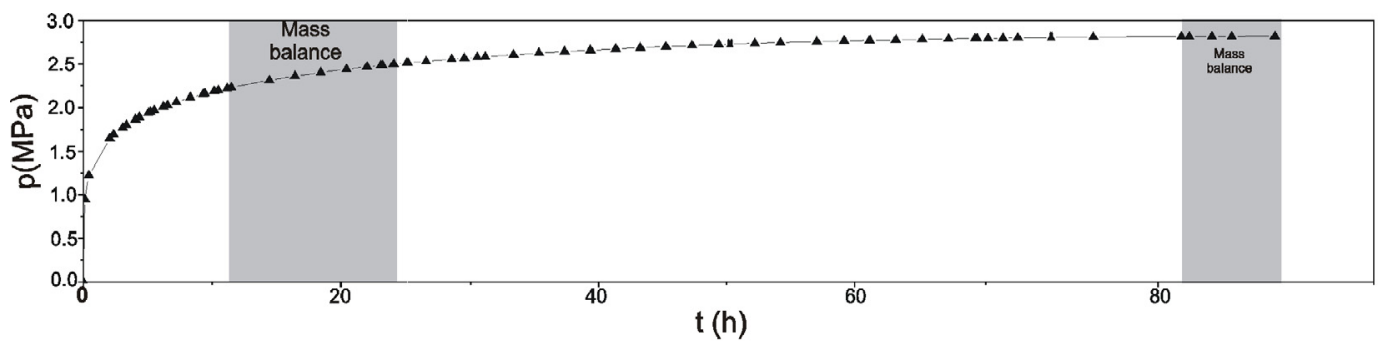

(a)

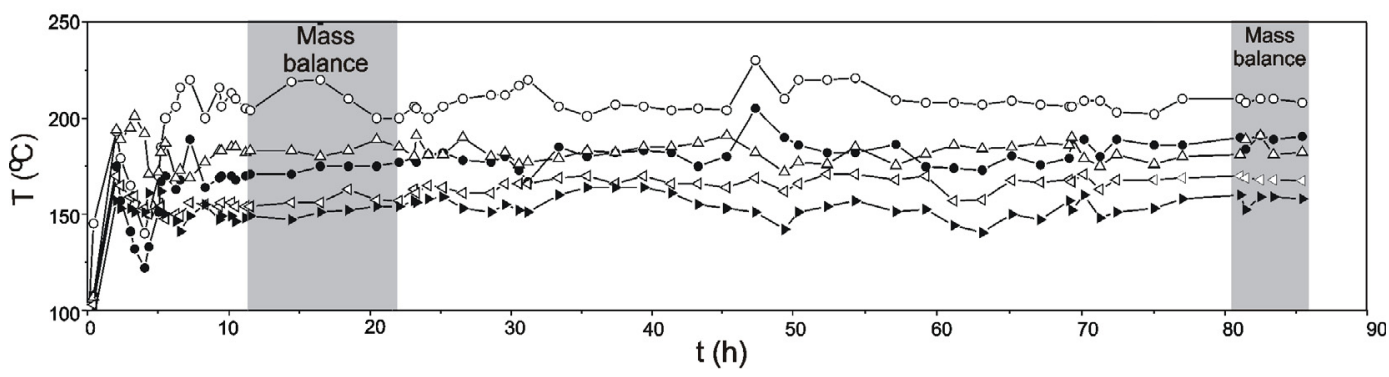

(b)

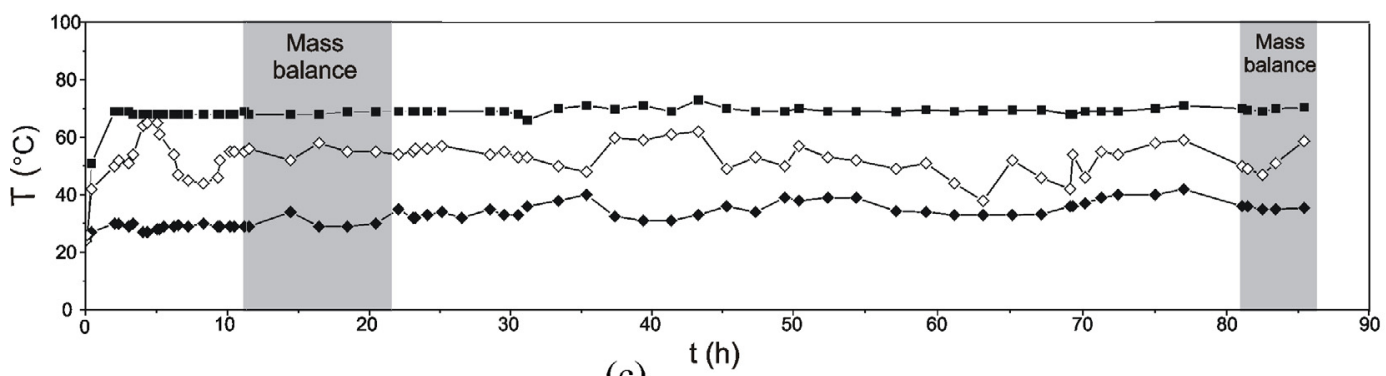

(c)

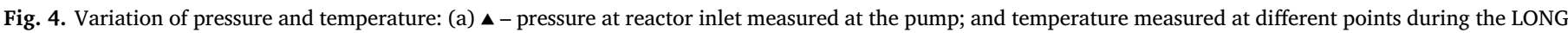

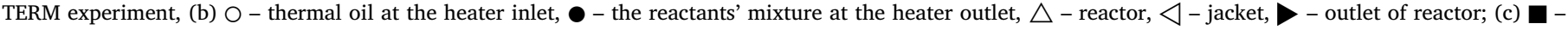
evaporator, $\diamond$ - condenser, $\diamond-$ cooler. 
Table 3

Mass balances realized during the Long Term test (LT- $t)$

\begin{tabular}{llllll}
\hline $\begin{array}{l}\text { Mass balance } \\
\text { experiment }\end{array}$ & Inlet & \multicolumn{5}{c}{ Outlet } \\
\cline { 2 - 6 } & Oil (kg) & Methanol (kg) & $\begin{array}{l}\text { Raw } \\
\text { ester } \\
\text { phase } \\
\text { (kg) }\end{array}$ & $\begin{array}{l}\text { Raw } \\
\text { glycerol } \\
\text { phase }(\mathrm{kg})\end{array}$ & $\begin{array}{l}\text { Recovered } \\
\text { methanol } \\
(\mathrm{kg})\end{array}$ \\
\hline $\begin{array}{l}\text { First } \\
\text { Second }\end{array}$ & 31.91 & 20.64 & 32.75 & 9.55 & 10.25 \\
$11.2^{*}$ & $10^{*}$ & 12.56 & 2.75 & 5.89 \\
\hline
\end{tabular}

* The value of methanol-to-oil molar ratio during the 2nd mass balance was changed to $25: 1$.

Table 4

The average composition of the ester phase.

\begin{tabular}{lllll}
\hline Mass balance & FAME (\%) & MAG (\%) & DAG (\%) & TAG (\%) \\
\hline First & 98.56 & 0.53 & 0.91 & 0.00 \\
Second & 97.49 & 1.08 & 1.21 & 0.22 \\
\hline
\end{tabular}

Table 3 while the composition of esters phase determined by HPLC analysis is shown in Table 4.

The samples of crude ester and glycerol phases $(1 \mathrm{~L}$ each) collected during the mass balance checking were left to stay for 2 days. The phases were separated and the following layers were detected:

- The crude esters sample (vol\%): the FAME phase (upper layer) about $93 \%$ and the glycerol phase (lower layer) $4 \%$ while the evaporated methanol was approximately $3 \%$.

- The crude glycerol sample (vol\%): methanol (upper layer) $3.2 \%$, FAME phase (middle layer) $2.5 \%$ and lower layer $87.3 \%$ as a mixture of glycerol $(80.3 \%)$ and methanol (7\%).

Based on this observation, it might be concluded that the final products collected during the FIRST mass balance contained $30.8 \mathrm{~kg}$ of pure ester phase ( $30.4 \mathrm{~kg}$ of FAMEs and $0.4 \mathrm{~kg}$ of DAGs and MAGs), $0.09 \mathrm{~kg}$ of methanol and $1.83 \mathrm{~kg}$ of glycerol.
This analysis showed that the FAME content was very high in the esters phase analyzed during the $L T-t$ (Table 4 ). In both mass balances FAME content was higher than $96.5 \%$, meeting the requirements of the biodiesel standard specifications (EN 14214). It was worth mentioning that during the $L T-t$, the contents of DAGs and MAGs were very low, but still slightly higher than those defined by standards $(0.2 \%$ for DAG and $0.8 \%$ for MAG). TAGs were not detected in the esters phase of the FIRST mass balance but they started to appear at the end of the SECOND mass balance of $L T-t$, being close to the standard limit $(0.2 \%)$. Although the conversion of TAGs was still very high $(99.8 \%)$, the yield of FAME dropped to $97.5 \%$. This result agreed with the observed changes in the esters phase composition during the soybean oil transesterification in the repeated use of the catalyst in the batch transesterification [9].

\subsubsection{Catalyst deactivation during pilot plant experiment}

During $85 \mathrm{~h}$ of the $L T-t$, a small fluctuation of the esters phase composition was observed. However, there were no enough data to predict exactly the catalyst deactivation during $85 \mathrm{~h}$ of its use. The simple calculation, mentioned above based on data collected in the batch process, indicated that the used amount of $\mathrm{MnCO}_{3} / \mathrm{Na}$-silicate catalyst $(10 \mathrm{~kg}$ ) would be active for at least 8-9 days of the continuous process and the data of $L T-t$ supported this expectation. At the same time, a gradual increase of the pressure in the PBTR was observed (Fig. 4a). The pressure should be enhanced for keeping the capacity of the pilot plant at the designed value, which was attributed to the blocking of the interparticle space with TAGs and the side products formed at a high temperature as a result of the oil polymerization.

For defining the actual status of the used catalyst in the PBTR after the $L T-t$, the samples were withdrawn from the bottom and the middle part of the PBTR and analyzed by XRD, TG/DTA and FTIR. Fig. 5 shows the XRD pattern of the $\mathrm{MnCO}_{3} / \mathrm{Na}$-silicate sample (washed and centrifuged with ethanol).

The presence of rhombohedral structure of $\mathrm{MnCO}_{3}$ was consistent with the literature values (JCPDS Card 83-1763). Since the XRD pattern was very similar to the XRD pattern of the fresh catalyst [9] it was concluded that the catalyst did not undergo any noticeable structural changes during the $85 \mathrm{~h}$ of the $L T-t$.

Thermal behavior of the as-taken (without washing) $\mathrm{MnCO}_{3} / \mathrm{Na}$ -

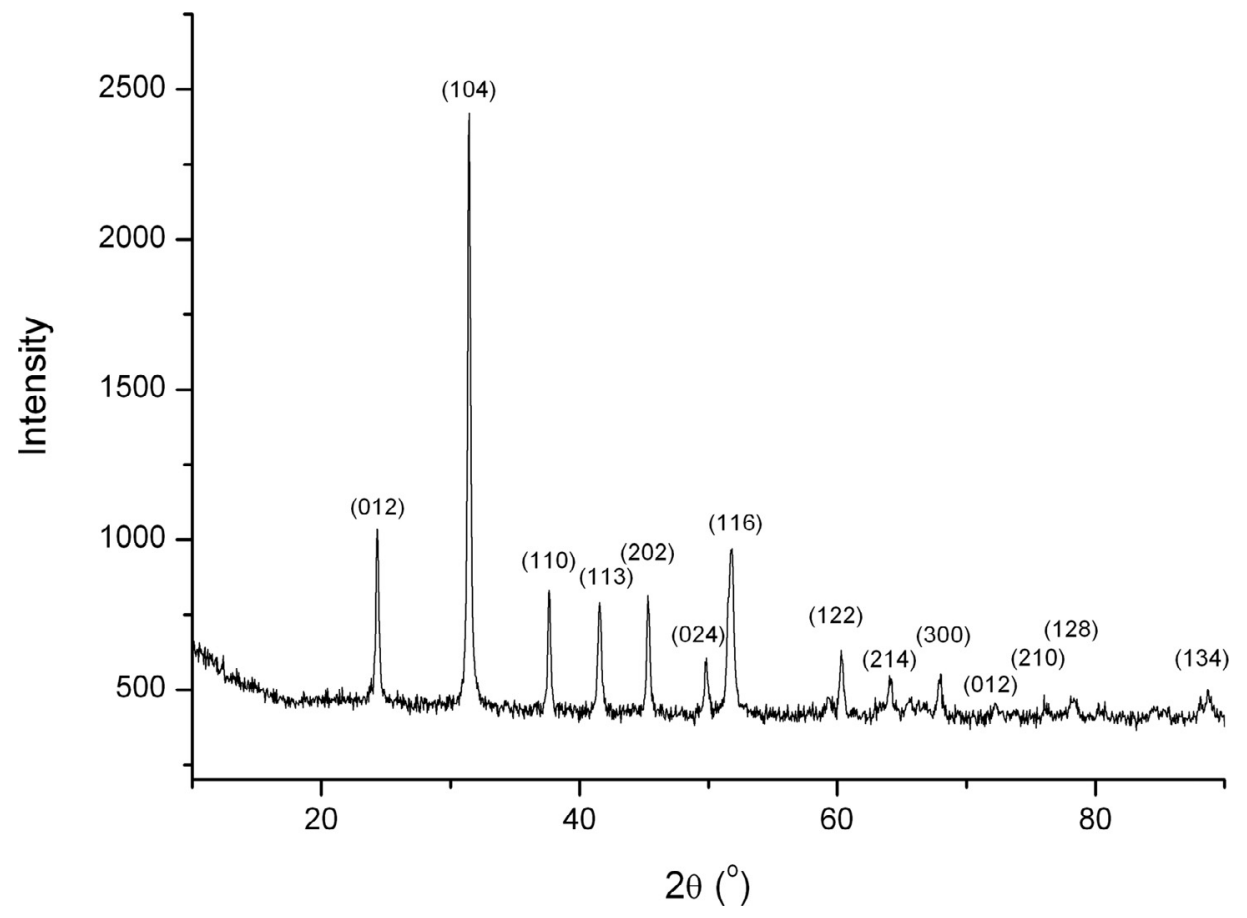

Fig. 5. XRD pattern of the $\mathrm{MnCO}_{3} / \mathrm{Na}$-silicate catalyst taken from the middle part of the PBTR after $85 \mathrm{~h}$ of the $L T$ - $t$ performed at $175^{\circ} \mathrm{C}$ and $2.5 \mathrm{MPa}$. 


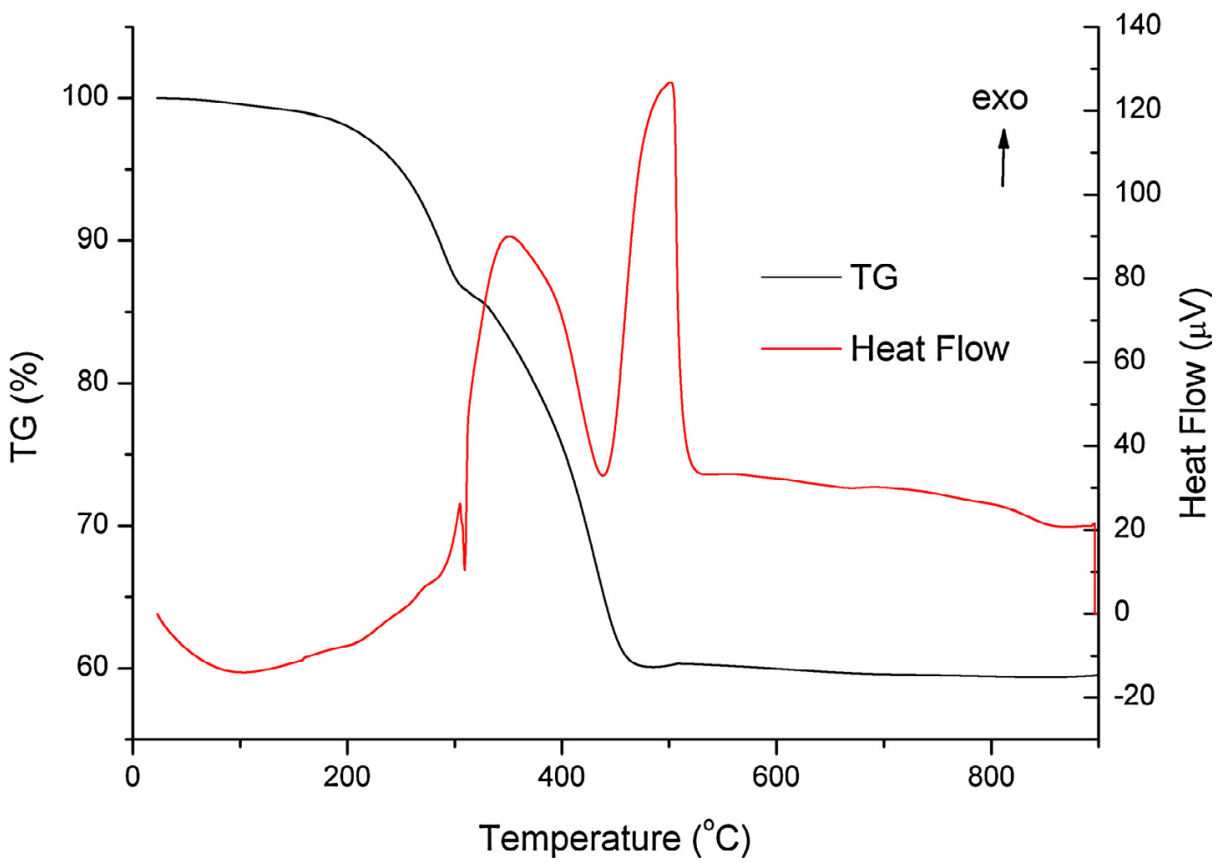

Fig. 6. TG/DTA analysis (heating rate: $20 \mathrm{~K} / \mathrm{min}$ ) of the $\mathrm{MnCO}_{3} / \mathrm{Na}$-silicate catalyst sample taken from the middle part of the PBTR after $85 \mathrm{~h}$ of the $L T-t$.

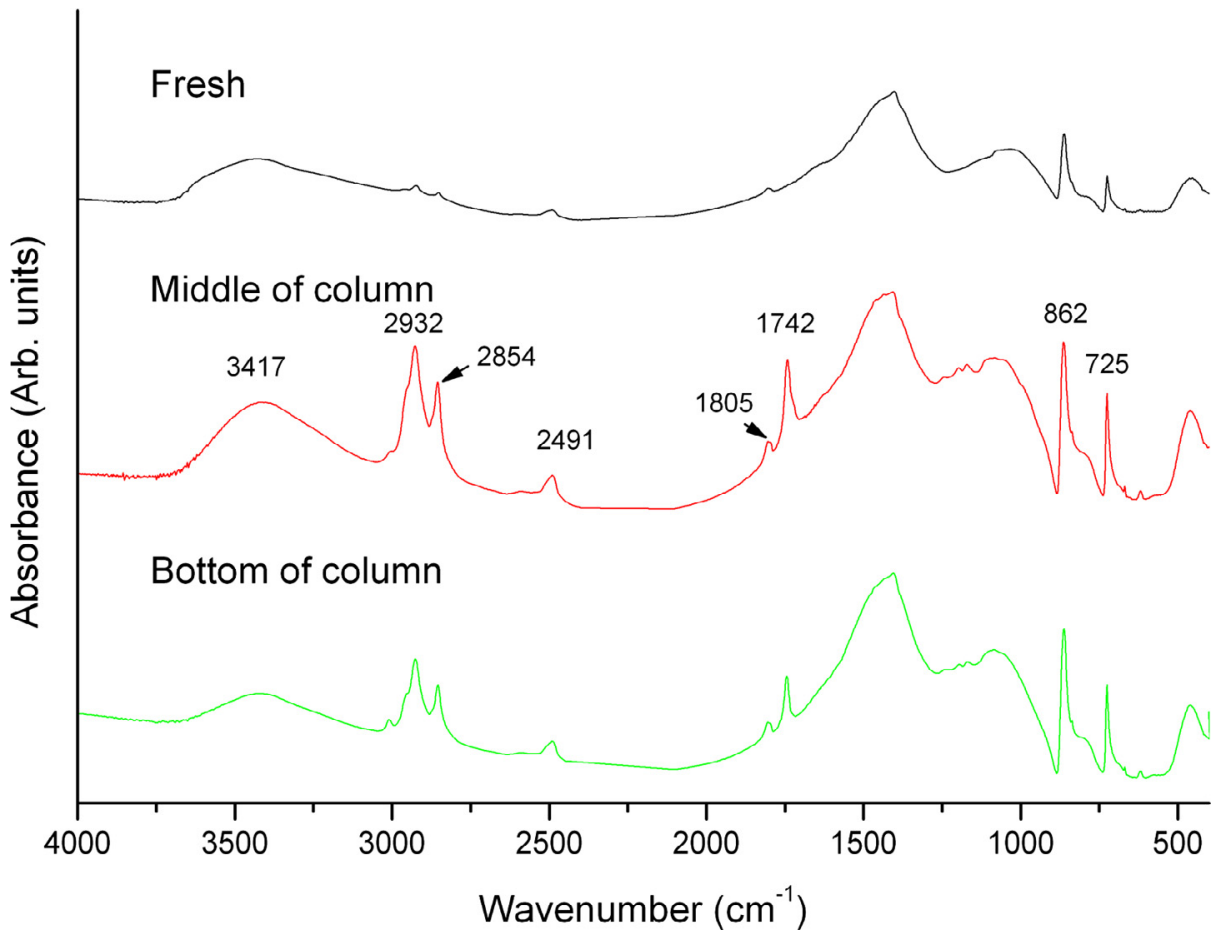

Fig. 7. FTIR spectra of the fresh and used catalyst collected from the bottom and middle part of the PBTR after $85 \mathrm{~h}$ of the $L T$-t.

silicate is shown in Fig. 6.

The mass change indicated a weight loss at about $320^{\circ} \mathrm{C}(16 \%)$, which might be attributed to the release of crystalline water and the compounds adsorbed on the catalyst surface (composed of FAMEs, glycerol, and traces of TAGs, DAGs and MAGs). The second mass change was observed in the temperature range from 320 to $500^{\circ} \mathrm{C}$, with an endothermic peak at about $440{ }^{\circ} \mathrm{C}$. It might be attributed to the thermal decomposition of $\mathrm{MnCO}_{3}$ as well to the degradation of the reactants and the products. The total weight loss was about $40 \%$, which was $10 \%$ higher than that found for the fresh catalyst [9]. Therefore, it was concluded that a part $(10 \%)$ of oil phase was adsorbed on the catalyst surface.

The FTIR spectra of the fresh and used catalysts are shown in Fig. 7 for comparison.

The broad band of the spectra with the maximum at about $3400 \mathrm{~cm}^{-1}$ might be attributed to the hydrogen (H)-bonded stretching vibration of the $\mathrm{O}-\mathrm{H}$ group, and could be assigned to the water (moisture) adsorbed from air and/or the reaction mixture on the catalyst surface. The peaks at 2932, 1742 and $725 \mathrm{~cm}^{-1}$ might be assigned to $\mathrm{C}-\mathrm{H}, \mathrm{C}-\mathrm{O}$ and $\mathrm{C}-\mathrm{C}$ functional groups, respectively, while the peak at $862 \mathrm{~cm}^{-1}$ corresponded to the bending vibration of $\mathrm{CO}_{3}{ }^{2-}$ in $\mathrm{MnCO}_{3}$. 
It was found that the absorbance values from the wavelength region of $3700-3075 \mathrm{~cm}^{-1}$ might be used for estimating the moisture content in the biodiesel samples [47]. The broad peak in this region was more pronounced for the samples taken from the middle and bottom parts of the reactor than that of the fresh sample suggesting the presence of water in the reaction mixture. Furthermore, remarkably higher intensities of the peaks at 2932, 2854 and $1742 \mathrm{~cm}^{-1}$ for the samples of the used catalyst, compared to that for the fresh catalyst, indicate the existence of different compounds from the reaction mixture, which were adsorbed on the catalyst surface.

\section{Conclusion}

The pilot plant with the capacity of $100 \mathrm{~L}$ of biodiesel per day was successfully designed and tested for biodiesel production from soybean oil catalyzed by $\mathrm{MnCO}_{3} / \mathrm{Na}$-silicate. The kinetic model with the parameters determined based on the analysis of the experiments realized in batch autoclave at $175^{\circ} \mathrm{C}$ and 25 bar over $\mathrm{MnCO}_{3} / \mathrm{Na}$-silicate as a catalyst and taking into account the influence of temperature and catalyst loading on the apparent reaction rate constant, was used for the design of PBTR as a main equipment of corresponding pilot plant.

Test of continuous operation was used to prove designed capacity and operational characteristics of pilot plant unit. Investigation was started using PBTR filled only with glass beads for $11 \mathrm{~h}$, and then, the catalyzed transesterification of soybean oil with $\mathrm{MnCO}_{3} / \mathrm{Na}$-silicate as catalyst was realized during $85 \mathrm{~h}$ of continuous operation. Two complete mass balances performed for detailed examination of the content of produced biodiesel revealed high TAG conversion (99.8\%) and FAME yield over $97.5 \%$, while the sample of used catalyst withdrawn from reactor after $85 \mathrm{~h}$ of continuous process did not show any noticeable structural changes. The results of the performed tests in pilot plant showed a good starting point for further experiments planned to be done in order to improve constructed biodiesel production facility and to test other types of catalysts.

\section{Acknowledgements}

This study was supported by the International S\&T Cooperation Program of China (Grant No. 2013DFG92250) as well as the research Grant No. 45001 of the Ministry of Education, Science and Technological Development of the Republic of Serbia.

\section{References}

[1] Kouzu M, Hidaka J suke, Komichi Y, Nakano H, Yamamoto M. A process to transesterify vegetable oil with methanol in the presence of quick lime bit functioning as solid base catalyst. Fuel 2009;88:1983-90. http://dx.doi.org/10.1016/j.fuel.2009. 03.013.

[2] Miladinović MR, Krstić JB, Tasić MB, Stamenković OS, Veljković VB. A kinetic study of quicklime-catalyzed sunflower oil methanolysis. Chem Eng Res Des 2014;92:1740-52. http://dx.doi.org/10.1016/j.cherd.2013.11.023.

[3] Reyero I, Arzamendi G, Gandía LM. Heterogenization of the biodiesel synthesis catalysis: $\mathrm{CaO}$ and novel calcium compounds as transesterification catalysts. Chem Eng Res Des 2014;92:1519-30. http://dx.doi.org/10.1016/j.cherd.2013.11.017.

[4] Roschat W, Phewphong S, Thangthong A, Moonsin P, Yoosuk B, Kaewpuang T, et al. Catalytic performance enhancement of $\mathrm{CaO}$ by hydration-dehydration process for biodiesel production at room temperature. Energy Convers Manage 2018;165:1-7. http://dx.doi.org/10.1016/j.enconman.2018.03.047.

[5] Jookjantra K, Wongwuttanasatian T. Optimisation of biodiesel production from refined palm oil with heterogeneous $\mathrm{CaO}$ catalyst using pulse ultrasonic waves under a vacuum condition. Energy Convers Manage 2017;154:1-10. http://dx.doi. org/10.1016/j.enconman.2017.10.050.

[6] Kesic Z, Lukic I, Zdujic M, Mojovic L, Skala D. Calcium oxide based catalysts for biodiesel production: a review. Chem Ind Chem Eng Q 2016;22:391-408. http://dx. doi.org/10.2298/CICEQ160203010K.

[7] Guo F, Wei NN, Xiu ZL, Fang Z. Transesterification mechanism of soybean oil to biodiesel catalyzed by calcined sodium silicate. Fuel 2012;93:468-72. http://dx. doi.org/10.1016/j.fuel.2011.08.064.

[8] Wan L, Liu H, Nasreen S, Lukic I, Skala D. High temperature transesterification of soybean oil with methanol using manganese carbonate as catalyst. Chem Ind Chem Eng Q 2018;124:9-22. http://dx.doi.org/10.2298/CICEQ170221013W.

[9] Zhang Y, Liu H, Zhu X, Lukic I, Zdujic M, Shen X, et al. Biodiesel synthesis and kinetic analysis based on $\mathrm{MnCO}_{3} / \mathrm{Na}$ silicate as heterogeneous catalyst. J Serb Chem Soc 2018;83:345-65. http://dx.doi.org/10.2298/JSC170612005Z.

[10] Yang X-X, Wang Y-T, Yang Y-T, Feng E-Z, Luo J, Zhang F, et al. Catalytic transesterification to biodiesel at room temperature over several solid bases. Energy Convers Manage 2018;164:112-21. http://dx.doi.org/10.1016/j.enconman.2018. 02.085 .

[11] Feng Y, Zhang A, Li J, He B. A continuous process for biodiesel production in a fixed bed reactor packed with cation-exchange resin as heterogeneous catalyst. Bioresour Technol 2011;102:3607-9. http://dx.doi.org/10.1016/j.biortech.2010.10.115.

[12] Ren Y, He B, Yan F, Wang H, Cheng Y, Lin L, et al. Continuous biodiesel production in a fixed bed reactor packed with anion-exchange resin as heterogeneous catalyst. Bioresour Technol 2012;113:19-22. http://dx.doi.org/10.1016/j.biortech.2011.10. 103.

[13] Xiao Y, Gao L, Xiao G, Fu B, Niu L. Experimental and modeling study of continuous catalytic transesterification to biodiesel in a bench-scale fixed-bed reactor. Ind Eng Chem Res 2012;51:11860-5. http://dx.doi.org/10.1021/ie202312z.

[14] Lukić I, Kesić Ž, Maksimović S, Zdujić M, Liu H, Krstić J, et al. Kinetics of sunflower and used vegetable oil methanolysis catalyzed by CaO-ZnO. Fuel 2013;113:367-78. http://dx.doi.org/10.1016/j.fuel.2013.05.093.

[15] Stamenković OS, Veljković VB, Todorović ZB, Lazić ML, Banković-Ilić IB, Skala DU. Modeling the kinetics of calcium hydroxide catalyzed methanolysis of sunflower oil. Bioresour Technol 2010;101:4423-30. http://dx.doi.org/10.1016/j.biortech.2010. 01.109.

[16] Veljković VB, Stamenković OS, Todorović ZB, Lazić ML, Skala DU. Kinetics of sunflower oil methanolysis catalyzed by calcium oxide. Fuel 2009;88:1554-62. http://dx.doi.org/10.1016/j.fuel.2009.02.013.

[17] Chantrasa A, Phlernjai N, Goodwin JG. Kinetics of hydrotalcite catalyzed transesterification of tricaprylin and methanol for biodiesel synthesis. Chem Eng $\mathrm{J}$ 2011;168:333-40. http://dx.doi.org/10.1016/j.cej.2011.01.033.

[18] Dossin TF, Reyniers MF, Marin GB. Kinetics of heterogeneously MgO-catalyzed transesterification. Appl Catal B Environ 2006;62:35-45. http://dx.doi.org/10. 1016/j.apcatb.2005.04.005.

[19] Ilgen O, Akin AN. Determination of reaction orders for the transesterification of canola oil with methanol by using $\mathrm{KOH} / \mathrm{MgO}$ as a heterogeneous catalyst. Appl Catal B Environ 2012;126:342-6. http://dx.doi.org/10.1016/j.apcatb.2012.07.034.

[20] Xiao Y, Gao L, Xiao G, Lv J. Kinetics of the transesterification reaction catalyzed by solid base in a fixed-bed reactor. Energy Fuel 2010;24:5829-33. http://dx.doi.org/ 10.1021/ef100966t.

[21] Hsieh LS, Kumar U, Wu JCS. Continuous production of biodiesel in a packed-bed reactor using shell-core structural $\mathrm{Ca}\left(\mathrm{C}_{3} \mathrm{H}_{7} \mathrm{O}_{3}\right)_{2} / \mathrm{CaCO}_{3}$ catalyst. Chem Eng $\mathrm{J}$ 2010;158:250-6. http://dx.doi.org/10.1016/j.cej.2010.01.025.

[22] Kapil A, Wilson K, Lee AF, Sadhukhan J. Kinetic Modeling studies of heterogeneously catalyzed biodiesel synthesis reactions. Ind Eng Chem Res 2011:110107112719009. http://dx.doi.org/10.1021/ie101403f.

[23] Miladinovic M, Tasic M, Stamenkovic O, Veljkovic V, Skala D. Further study on kinetic modeling of sunflower oil methanolysis catalyzed by calcium-based catalysts. Chem Ind Chem Eng Q 2016;22:137-44. http://dx.doi.org/10.2298/ CICEQ150618027M.

[24] Tasić MB, Miladinović MR, Stamenković OS, Veljković VB, Skala DU. Kinetic modeling of sunflower oil methanolysis catalyzed by calcium-based catalysts. Chem Eng Technol 2015;38:1550-6. http://dx.doi.org/10.1002/ceat.201500076.

[25] Liu Y, Wang L. Biodiesel production from rapeseed deodorizer distillate in a packed column reactor. Chem Eng Process Process Intensif 2009;48:1152-6. http://dx.doi. org/10.1016/j.cep.2009.04.001.

[26] Marinković DM, Miladinović MR, Avramović JM, Krstić IB, Stanković MV, Stamenković OS, et al. Kinetic modeling and optimization of sunflower oil methanolysis catalyzed by spherically-shaped $\mathrm{CaO} / \gamma-\mathrm{Al}_{2} \mathrm{O}_{3}$ catalyst. Energe Convers Manage 2018;163:122-33. http://dx.doi.org/10.1016/j.enconman.2018.02.048.

[27] Miladinović MR, Stamenković OS, Veljković VB, Skala DU. Continuous sunflower oil methanolysis over quicklime in a packed-bed tubular reactor. Fuel 2015;154:301-7. http://dx.doi.org/10.1016/j.fuel.2015.03.057.

[28] Miladinović MR, Stamenković OS, Banković PT, Milutinović-Nikolić AD, Jovanović DM, Veljković VB. Modeling and optimization of sunflower oil methanolysis over quicklime bits in a packed bed tubular reactor using the response surface methodology. Energy Convers Manage 2016;130:25-33. http://dx.doi.org/10.1016/j. enconman.2016.10.020.

[29] Bournay L, Casanave D, Delfort B, Hillion G, Chodorge JA. New heterogeneous process for biodiesel production: a way to improve the quality and the value of the crude glycerin produced by biodiesel plants. Catal Today 2005;106:190-2. http:// dx.doi.org/10.1016/j.cattod.2005.07.181.

[30] McNeff CV, McNeff LC, Yan B, Nowlan DT, Rasmussen M, Gyberg AE, et al. A continuous catalytic system for biodiesel production. Appl Catal A Gen 2008;343:39-48. http://dx.doi.org/10.1016/j.apcata.2008.03.019.

[31] Melero JA, Bautista LF, Iglesias J, Morales G, Sánchez-Vazquez R. Production of biodiesel from waste cooking oil in a continuous packed bed reactor with an agglomerated Zr-SBA-15/bentonite catalyst. Appl Catal B Environ 2014;145:197-204. http://dx.doi.org/10.1016/j.apcatb.2013.02.050.

[32] Allain F, Portha J-F, Girot E, Falk L, Dandeu A, Coupard V. Estimation of kinetic parameters and diffusion coefficients for the transesterification of triolein with methanol on a solid $\mathrm{ZnAl}_{2} \mathrm{O}_{4}$ catalyst. Chem Eng J 2016;283:833-45. http://dx.doi. org/10.1016/j.cej.2015.07.075.

[33] Lin HC, Tan CS. Continuous transesterification of coconut oil with pressurized methanol in the presence of a heterogeneous catalyst. J Taiwan Inst Chem Eng 2014;45:495-503. http://dx.doi.org/10.1016/j.jtice.2013.06.015.

[34] Tran D-T, Chang J-S, Lee D-J. Recent insights into continuous-flow biodiesel production via catalytic and non-catalytic transesterification processes. Appl Energy 
2017;185:376-409. http://dx.doi.org/10.1016/j.apenergy.2016.11.006.

[35] Kouzu M, Fujimori A, Suzuki T, Koshi K, Moriyasu H. Industrial feasibility of powdery $\mathrm{CaO}$ catalyst for production of biodiesel. Fuel Process Technol 2017;165:94-101. http://dx.doi.org/10.1016/j.fuproc.2017.05.014.

[36] Glisic SB, Orlović AM. Review of biodiesel synthesis from waste oil under elevated pressure and temperature: phase equilibrium, reaction kinetics, process design and techno-economic study. Renew Sustain Energy Rev 2014;31:708-25. http://dx.doi. org/10.1016/j.rser.2013.12.003.

[37] Nasreen S, Liu H, Lukic I, Qurashi L, Skala D. Heterogeneous kinetics of vegetable oil transesterification at high temperature. Chem Ind Chem Eng Q 2016;22:419-29. http://dx.doi.org/10.2298/CICEQ160107011N.

[38] Di Serio M, Ledda M, Cozzolino M, Minutillo G, Tesser R, Santacesaria E. Transesterification of soybean oil to biodiesel by using heterogeneous basic catalysts. Ind Eng Chem Res 2006;45:3009-14. http://dx.doi.org/10.1021/ie051402o.

[39] Suppes G. Transesterification of soybean oil with zeolite and metal catalysts. Appl Catal A Gen 2004:257:213-23. http://dx.doi.org/10.1016/j. apcata.2003.07.010.

[40] Silva CCCM, Ribeiro NFP, Souza MMVM, Aranda DAG. Biodiesel production from soybean oil and methanol using hydrotalcites as catalyst. Fuel Process Technol 2010;91:205-10. http://dx.doi.org/10.1016/j.fuproc.2009.09.019.

[41] Lee HV, Juan JC, Binti Abdullah NF, Nizah Mf R, Taufiq-Yap YH. Heterogeneous base catalysts for edible palm and non-edible Jatropha-based biodiesel production. Chem Cent J 2014;8:1-9. http://dx.doi.org/10.1186/1752-153X-8-30.

[42] Umdu ES, Tuncer M, Seker E. Transesterification of nannochloropsis oculata microalga's lipid to biodiesel on $\mathrm{Al}_{2} \mathrm{O}_{3}$ supported $\mathrm{CaO}$ and $\mathrm{MgO}$ catalysts. Bioresour Technol 2009;100:2828-31. http://dx.doi.org/10.1016/j.biortech.2008.12.027.

[43] Wan L, Liu H, Skala D. Biodiesel production from soybean oil in subcritical methanol using $\mathrm{MnCO}_{3} / \mathrm{ZnO}$ as catalyst. Appl Catal B Environ 2014;152-153:352-9. http://dx.doi.org/10.1016/j.apcatb.2014.01.033.

[44] Yin JZ, Ma Z, Hu DP, Xiu ZL, Wang TH. Biodiesel production from subcritical methanol transesterification of soybean oil with sodium silicate. Energy Fuel 2010;24:3179-82. http://dx.doi.org/10.1021/ef100101m.

[45] Lukić I, Krstić J, Glišić S, Jovanović D, Skala D. Biodiesel synthesis using $\mathrm{K}_{2} \mathrm{CO}_{3} / \mathrm{Al}$ O-Si aerogel catalysts. J Serb Chem Soc 2010;75:789-801. http://dx.doi.org/10. 2298/JSC090707047L.

[46] Glišić S, Lukć I, Skala D. Biodiesel synthesis at high pressure and temperature: analysis of energy consumption on industrial scale. Bioresour Technol 2009;100:6347-54. http://dx.doi.org/10.1016/j.biortech.2009.07.024.

[47] Mirghani MES, Kabbashi NA, Alam MZ, Qudsieh IY, Alkatib MFR. Rapid Method for the determination of moisture content in biodiesel using FTIR spectroscopy. J Am Oil Chem Soc 2011;88:1897-904. http://dx.doi.org/10.1007/s11746-011-1866-0. 